\title{
The Molecular Effect of Curcumin Subsidized by Radiation on HepG2 cell lines
}

Kaed A. ${ }^{1}$, Hassan N. ${ }^{2}$, El-Maghraby T. ${ }^{1}$

Received: 30/07/2018

Accepted: 16/09/2018

E.mail:azzakaed60@gmail.com

\section{KEYWORDS}

Curcumin;

Hepatocellular

Carcinoma; Gamma-

Radiation; p53; Her2/

neu; MMP9.

\section{ABSTRACT}

Cancer is a major health problem around the world. Cancer treatment depends on radiation therapy sometimes in combination with chemotherapy or hormonal therapy. The treatment of cancer with radiation and chemotherapy cause several unwanted harmful side effects. Turmeric (Curcuma longa), is a type of herb widely used as a spice. Recent researches have shown that curcumin, the active component of turmeric possesses anticancer properties. This study aimed to evaluate the effect of $\gamma$-radiation and curcumin each of them alone or combined on HepG2 cell line proliferation, p53, Her2/neu, and MMP9 gene expression, and total antioxidant capacity. HepG2 cells were exposed to $\gamma$-radiation (R), or treated with different concentrations of curcumin alone or combined with each other. The cell viability was examined by MTT assay. Gene expression of $\mathrm{p} 53$, Her2/neu, and MMP9 were evaluated by using real-time QPCR. The total antioxidant capacity (TAC) was also measured. Curcumin or R alone or combined decreased cell viability and induced cell death in a dose-and time-dependent manner when compared to untreated group. Curcumin and $\mathrm{R}$ induced $\mathrm{p} 53$ gene expression, while reduced Her2/neu, and MMP9 expression. Furthermore, the TAC was decreased in the treated groups compared to the untreated. Conclusion: Curcumin can sensitize HepG2 cells to radiation and would potentiate the effect of radiotherapy in cancer..

1. Molecular Biology, Radiation Biology Department National Centre for Radiation Research and Technology, Atomic Energy Authority, Cairo, Egypt.

2. Zoology Department, Faculty of Science, Ain Shams University. 


\section{INTRODUCTION}

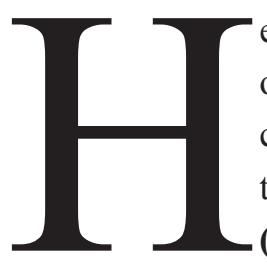

epatocellular carcinoma (HCC) is one of the most common malignancies in the world, leading to more than 500000 deaths every year (Fung and Lok, 2005). Most HCC cases $(>80 \%)$ occur in either sub-Saharan Africa or Eastern Asia. HCC cases in China alone account for more than $40 \%$ of all cases in the world (El-Serag and Rudolph, 2007). Treatment of HCC is still a great challenge for oncologists because most HCC patients are diagnosed at its advanced stage with metastasis (Rivenbark and Coleman, 2007). In Egypt, HCC is ranked as the $6^{\text {th }}$ most common cancer in women and second in men (Ziada et al., 2016). Cancer is a genetically rooted disease, some genes were found to play critical roles in HCC (Badra et al., 2010).

p53 gene is the tumor suppressor gene most frequently mutated in human tumors and are the most common in HCC tumor (Li et al., 2015). p53 has been described as "the guardian of the genome", referring to its role in conserving stability by preventing genome mutation (Li et al., 2015). The cellular concentration of p53 must be regulated. While it can suppress tumors, high level of p53 may accelerate the aging process by excessive apoptosis. The major regulator of $\mathrm{p} 53$ is $\mathrm{Mdm} 2(\mathrm{Mdm} 2$ is an important negative regulator of the p53 tumor suppressor), which can trigger the degradation of p53 by the ubiquitin system (Wade $\boldsymbol{e t}$ al., 2006).

Her2/neu is a member of the human epidermal growth factor receptor (HER/EGFR/ERBB) family. Amplification or over-expression of this oncogene has been shown to play an important role in the development and progression of certain aggressive types of breast cancer (Mitri et al., 2012). The overexpression of the Her2/neu gene occurs in approximately 15-30\% of breast cancers (Mitri et al., 2012). It is strongly associated with increased disease recurrence and a poor prognosis (Tan and Yu 2007).
Matrix metalloproteinase 9 (MMP9) is involved in several human cancer. MMP9 can cause degradation of collagen of the extracellular matrix (Apoorv et al., 2015). Metalloproteinases (MMPs) are a family of zinc-dependent enzymes. These enzymes regulate many physiological events such as cell motility, and cell differentiation in tumour progression (Estella et al., 2012). MMP9 also can regulate embryonic development and wound healing ((Vandooren et al., 2013).

Radiotherapy is used for cancer treatment because it efficiently eradicate cancer cells with minimal damages to the surroundings. Meanwhile, ionizing radiation cause biological alterations, which can cause cellular damage. The cellular damage may lead to arrest of cell division, modified cell that carries some damage in its molecular structure which cannot cause cell death, loss tissue function, or cell death (El-Naggar, 2009).

Curcumin, a polyphenol derived from the plant Curcuma longa, is considered a promising anticancer drug due to its efficient induction of proliferation arrest and apoptosis in a variety of tumor cells. Curcumin also exhibits pro-oxidant properties under certain conditions, such as high concentrations (e.g., 50 $\mathrm{mM}$ ), which were found to promote reactive oxygen species (ROS) generation (Aggarwal et al., 2003), while a low concentration of curcumin (e.g., $10 \mathrm{mM}$ ) reduced ROS generation (Chan et al., 2003). Both the antioxidant and pro-oxidant activities of curcumin are considered to be involved in anticancer activity (Aggarwal et al., 2003).

\section{MATERIAL AND METHODS:}

\section{Cell culture and reagents}

HepG2 cells (Hepatocellular carcinoma, human) cell line provided by Dr. Ali M (Center of Scientific Excellence for Influenza Viruses, National Research Centre, Egypt), was cultured in Dulbecco's Modified Eagles Medium (DMEM) (Lonza, Walkersville, MD, 
USA), containing 10\% fetal bovine serum (Gibco, Grand Island, NY), penicillin (100 units/ml, Gibco), and streptomycin $(100 \mu \mathrm{g} / \mathrm{ml}$, Gibco $)$. Dimethyl sulfoxide (DMSO) was used as solvent. The cell cultures were incubated at Class II biological safety cabinet, Incubator, $37^{\circ} \mathrm{C}, 5 \% \mathrm{CO}_{2}$, and checked daily.

\section{Cell culture treatment:}

The cell culture was treated with curcumin purchased from Bio Basic, Canada INC.). Curcumin treatment was prepared by dissolving curcumin powder in dimethyl sulfoxide (DMSO) to the concentration of $10,20,-40,80,160,320 \mu \mathrm{M}$, and or Gamma irradiation which was performed at the National Center for Radiation Research and Technology (NCRRT), Atomic Energy Authority, Cairo, Egypt, using an Atomic Energy of Canada Limited Commercial products (AECL) Gamma Cell-40 $\left({ }^{137} \mathrm{Cs}\right)$ biological irradiator. The plates were submitted to $2 \mathrm{~Gy}$ and $5 \mathrm{~Gy}$ in a single dose with a dose rate of $\sim 0.758 \mathrm{rad} / \mathrm{Sec}$, and incubated at $37^{\circ} \mathrm{C}, 5 \% \mathrm{CO}_{2}$ for 24,48 , and $72 \mathrm{~h}$.

\section{Cell viability assay (MTT):}

Cell viability was assessed by the methyl thiazol tetrazolium bromide (MTT) assay as described previously (Mosmann, 1983). HepG2 cells were plated in a 96-well microtiter plate at a density of $5 \times$ $10^{4}$ cells /well. The cells were treated with curcumin $(10,20,40,80,160$, and $320 \mu \mathrm{M})$ alone or with $\gamma$-irradiation then incubated for 24,48 , and $72 \mathrm{~h}$. After treatment, the cells were incubated with MTT solution $(5 \mathrm{mg} / \mathrm{ml})$ for $4 \mathrm{~h}$ at $37^{\circ} \mathrm{C}$. The formazan crystals formed were dissolved in DMSO at $37^{\circ} \mathrm{C}$ for $1 \mathrm{~h}$ in the dark, and the absorbance was read at $\chi \max 540 \mathrm{~nm}$ with $620 \mathrm{~nm}$ as reference wavelength by 96 -well microtiter plates (Greiner Bio-One, Germany).

\section{RNA extraction:}

RNA was extracted from harvested cells (HepG2 cell) using SV total RNA isolation Promega products with quantification of RNA concentrations with na- no-dropper. cDNA was synthesized then according to the instructions of cDNA synthesis kit (Fermentus, Thermo Fisher Scientific Inc, UK). Polymerase Chain Reaction (PCR) amplifications for cDNAs were accomplished in Rotor Gene 2000 real-time fluorescence thermal cycler (Corbett Ltd., Australia) with a heated lid $\left(105^{\circ} \mathrm{C}\right)$ based on the PCR programs. PCR conditions were 15 seconds (s) denaturation at $95^{\circ} \mathrm{C}, 30 \mathrm{~s}$ annealing at 55,58 or $60^{\circ} \mathrm{C}$ for each gene and $1 \mathrm{~min}$ of extension at $72^{\circ} \mathrm{C}$ for 45 cycles. Each cDNA fragment was amplified in duplicate for all target genes as well as GAPDH gene. All primers were purchased from (Jena Bioscience, Germany). Her2/neu and GAPDH primers were designed according to Cuadros et al. (2010), P53 (Li et al., 2015) and MMP9 (Estella et al., 2012).

For verifying the amplification specificity and distinguishing any artifacts from the specific amplicons, melting curves were generated by denaturing the PCR products by slowly increasing the temperature from $\left(65-99^{\circ} \mathrm{C}\right)$ with the rate $\left.0.1^{\circ} \mathrm{C} / \mathrm{sec}\right)$. PCR products also were run on $1.5 \%$ agarose gel to confirm that correct molecular sizes were present.

\section{Estimation of Total Antioxidant Capacity (TAC):}

Total antioxidant capacity was determined by using a commercially available kit (Biodiagnostic, Egypt) according to Koracevic et al. (2001).

\section{Statistical analysis:}

All experiments were repeated three and four times. Analysis of data was performed using analysis of variance (One-Way ANOVA) processed by SPSS software (Statistical Package for Social Science), followed by Less significant difference (LSD) with $P \leq 0.05$ considered statistically significant. 
Table (1) : Primers sequences for amplified genes using real-time QPCR.

\begin{tabular}{|c|c|c|c|c|}
\hline Gene & Strand & Sequence $5 \square-3$ & $\begin{array}{l}\text { Product } \\
\text { length } \\
\text { (bp) }\end{array}$ & $\begin{array}{l}\text { Anneling } \\
\left({ }^{\circ} \mathbf{C}\right)\end{array}$ \\
\hline P53 & $\begin{array}{l}\text { Forward } \\
\text { Reverse }\end{array}$ & $\begin{array}{l}\text { 5'-TCAACAAGATGTTTTGCCAACTG-3'MW: } 1337 \\
\text { 5'-ATGTGCTGTGACTGCTTGTAGATG-3’MW: } 1454\end{array}$ & 118 & $60^{\circ} \mathrm{C}$ \\
\hline MMP9 & $\begin{array}{l}\text { Forward } \\
\text { Reverse }\end{array}$ & $\begin{array}{c}\text { 5`-TGGGGGGCAACTCGGC-3` MW: } 634 \\
\text { 5`-GGAATGATCTAAGCCCAG-3`MW: } 857\end{array}$ & 224 & $58^{\circ} \mathrm{C}$ \\
\hline Her2/neu & $\begin{array}{l}\text { Forward } \\
\text { Reverse }\end{array}$ & $\begin{array}{l}\text { 5`-CCAGGACCTGCTGAACTGGT-3`MW: } 2631 \\
\text { 5’-TGTACGAGCCGCACATCC-3`MW: } 2702\end{array}$ & 72 & $55^{\circ} \mathrm{C}$ \\
\hline GAPDH & $\begin{array}{l}\text { Forward } \\
\text { Reverse }\end{array}$ & $\begin{array}{l}\text { 5'-GAAGATGGTGATGGGATTTC-3’ MW } 194 \\
\text { 5'-GAAGGTGAAGGTCGGAGTC-3’ MW } 419\end{array}$ & 226 & $55^{\circ} \mathrm{C}$ \\
\hline
\end{tabular}

\section{RESULTS}

Figure (1) shows the effect of curcumin with different concentrations on HepG2 cells at 24, 48, and $72 \mathrm{~h}$. There was a significant decrease in cell viability of cells treated with Curcumin in a doseand time-dependent manner. The mean values at $24 \mathrm{~h}$ were $75.59 \%, 65.837 \%, 65.8 \%, 46.98 \%, 46.78 \%$ and $41.265 \%$ with the concentrations of $10,20,40,80$, 160 and $320 \mu \mathrm{M}$ respectively. This effect increases slightly at $48 \mathrm{~h}$ the values were $71.91 \%, 58.88 \%$, $55.98 \%, 46.33 \%, 34.46 \%, 33.78 \%$ in concentrations of $10,20,40,80,160$, and $320 \mu \mathrm{M}$ respectively. But the highest cytotoxicity of curcumin was at $72 \mathrm{~h}$ and $320 \mu \mathrm{M}$ that was $11.46 \%$.

In figure (2) the results show the cytotoxicity effect of $2 \mathrm{~Gy} \gamma$-irradiation alone or with previous concentrations of curcumin. In case of $2 \mathrm{~Gy}$ alone there is a significant decrease in cell viability by the time, where at $24 \mathrm{~h}$ the cell viability was $89.86 \%$, at $48 \mathrm{~h}$ was $86.96 \%$, and $87.4 \%$ at $72 \mathrm{~h}$, but when $2 \mathrm{~Gy}$ was combined with curcumin there was a significant decrease in cell viability especially at doses above 40 $\mu \mathrm{M}$ and in $72 \mathrm{~h}$. The $\mathrm{IC}_{50}$ (inhibitory concentration $50 \%$ ) values at $72 \mathrm{~h}$ in $80 \mu \mathrm{M}$ was $55.3 \%$, in $160 \mu \mathrm{M}$ was $47.09 \%$, and in $320 \mu \mathrm{M}$ was $46.685 \%$.

Figure (3) illustrates the cell viability of 5Gy alone or after treatment with different concentrations of curcumin, which was significantly lower than in case of $2 \mathrm{~Gy}$, and $5 \mathrm{~Gy}$ irradiation and recorded $57.015 \%, 14.113 \%$, and $10.59 \%$ in 24,48 , and $72 \mathrm{~h}$ respectively. The cell death was also dramatically increased in HepG2 cells exposed to 5Gy combined with curcumin also by the time and concentration. In $24 \mathrm{~h} \mathrm{IC}_{50}$ was in 160 , and $320 \mu \mathrm{M} 46.13 \%$, and $46.04 \%$ respectively. The cell death increase significantly in $48 \mathrm{~h}$, and $72 \mathrm{~h}$ with all curcumin concentrations, and recorded $5.53 \%$ with $320 \mu \mathrm{M}$ at $72 \mathrm{~h}$.

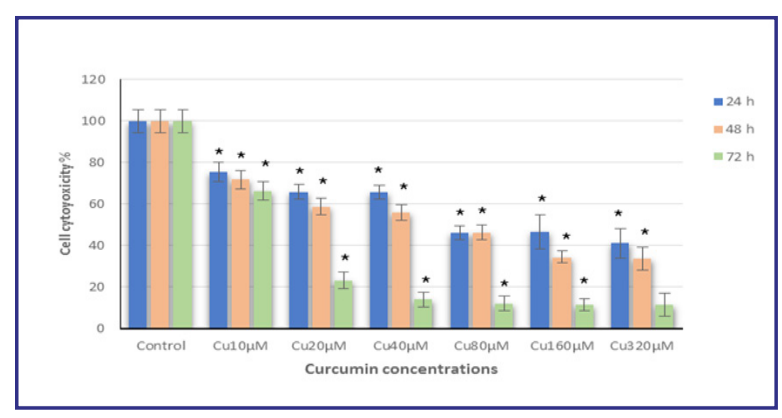

Fig. (1): The effect of curcumin on HepG 2 Cell cytotoxicity (MTT assay IC50) $( \pm \mathrm{SD}), \mathrm{P}<0.05$. 


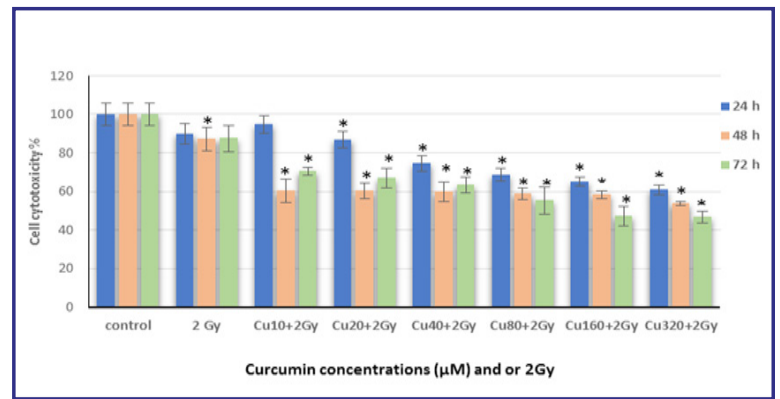

Fig. (2): Cell cytotoxicity assay (MTT assay IC50) ( \pm SD) as a result of exposure to $2 \mathrm{~Gy}$ ( $\gamma$-irradiation) alone or combined with different concentrations of curcumin, $\mathrm{P}<0.05$.

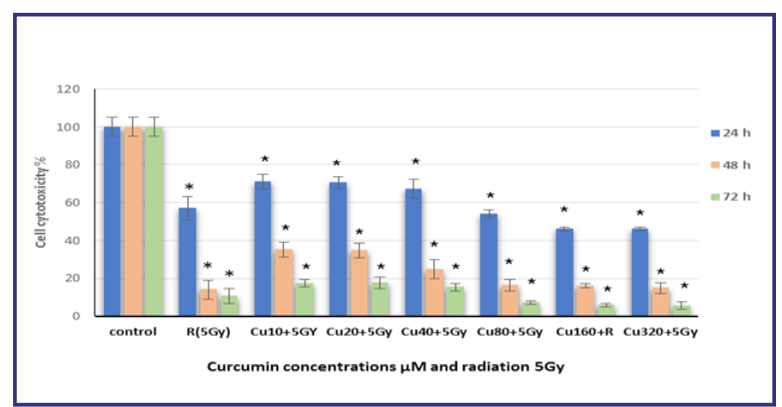

Fig. (3): Cell cytotoxicity assay (MTT assay IC50) ( \pm SD) as a result of exposure to 5Gy ( $\gamma$-irradiation) alone or combined with different concentrations of curcumin, $\mathrm{P} \leq 0.05$.

Figure (4) illustrates the effect of curcumin $(10,20,40$, and $80 \mu \mathrm{M})$ and $\gamma$-radiation (5Gy) each of them alone or combined with each other on p53 expression levels. 5Gy $\gamma$-irradiation alone increases the expression of $\mathrm{p} 53$ gene directly by the time. The highest expression was at $72 \mathrm{~h}$ and the mean was 2.64 \pm 0.38 fold relative to control. In the same direction, in case of treatment with curcumin alone there is a direct relation between expression of p53 gene time and concentrations. The largest increase was in $72 \mathrm{~h}$ and $80 \mu \mathrm{M}$ and the mean value was $5.2 \pm 5.17$. The combination of curcumin and 5Gy $\gamma$-irradiation revealed a significant increase in p53 expression, in case of $80 \mu \mathrm{M}$ and $5 \mathrm{~Gy}$ the expression was $10.12 \pm 0.66$ at $72 \mathrm{~h}$.

Her2/neu gene expression Figure (5) was down regulated by treatments of curcumin and this effect increase by concentrations and time. The expression mean values were down regulated to $0.4 \pm 0.16$, $0.267 \pm 0.115,0.26 \pm 0.08,0.097 \pm 0.06$ fold relative to control (HepG2 cell) with curcumin concentrations $10,20,40,80 \mu \mathrm{M}$ after $72 \mathrm{~h}$ respectively. The expression after exposure to $5 \mathrm{~Gy}$ alone was downregulated to $0.57 \pm 0.18,0.52 \pm 0.16,0.328 \pm 0.09$ fold change in $24,48,72 \mathrm{~h}$ respectively. In combined treatment of curcumin and $5 \mathrm{~Gy}$ the reduction increase and the highest reduction was $0.078 \pm 0.023$ in $80 \mu \mathrm{M}$ concentration and $72 \mathrm{~h}$.

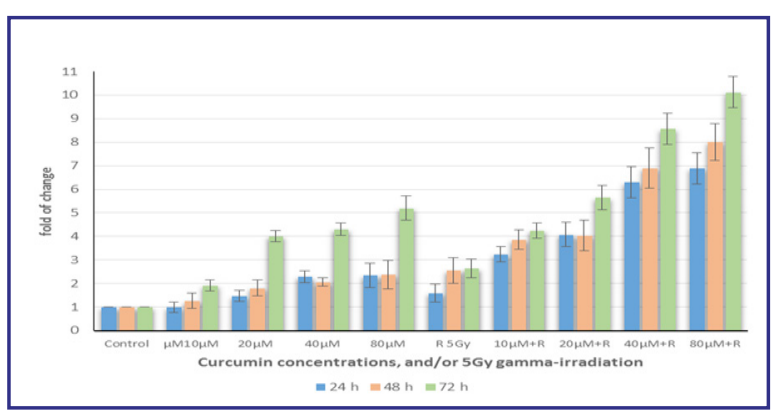

Fig. (4): P53 gene expression in HepG2 cell line treated with curcumin and/ or 5 Gy $\gamma$-iradiation \pm S.D, $\mathrm{P} \leq 0.05$.

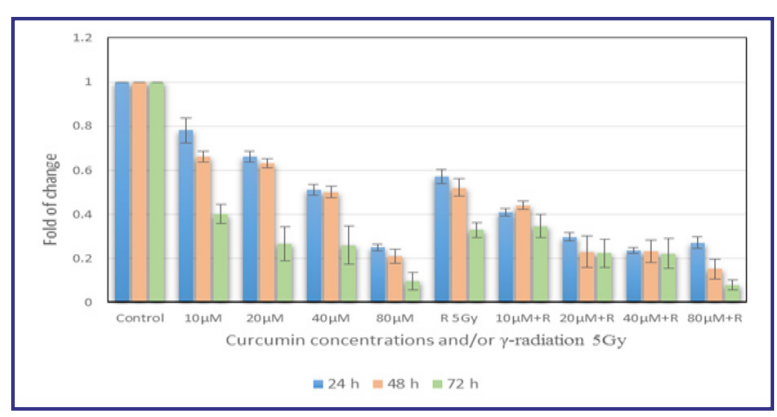

Fig. (5): Her2/neu gene expression in HepG2 cell line treated with curcumin and/ or $5 \mathrm{~Gy} \gamma$-irradiation \pm S.D, $\mathrm{P}$ $\leq 0.05$.

MMP9 gene expression decreased in a dose- and time-dependent manner when treated with curcumin, and/or 5Gy $\gamma$ radiation figure (6). The expressions after exposure to $5 \mathrm{~Gy}$ were $0.69 \pm 0.003,0.44 \pm$ $0.05,0.36 \pm 0.036$ fold decrease at 24,48 , and $72 \mathrm{~h}$ respectively compared to control group (HepG2 cell not treated). In case of curcumin alone MMP9 gene expression was down regulated at 48 , and $72 \mathrm{~h}$ more than at $24 \mathrm{~h}$. With high concentrations the effects increase. At $48 \mathrm{~h}$ the expressions were $0.312 \pm 0.07$, $0.22 \pm 0.05$ and $0.208 \pm 0.045$ fold decrease with 20, 40 and $80 \mu \mathrm{M}$ respectively. At $72 \mathrm{~h}$ the effects were the lowest. The values were $0.44 \pm 0.02,0.179 \pm$ 
$0.013,0.179 \pm 0.02$ and $0.138 \pm 0.005$ fold decrease with $10,20,40$ and $80 \mu \mathrm{M}$ respectively.

In combination between 5Gy and curcumin the expressions of MMP9 were dramatically down regulated with all curcumin concentrations at $72 \mathrm{~h}$, and was $0.059 \pm 0.002$ and $0.0236 \pm 0.001$ fold decrease with $40,80 \mu \mathrm{M}$ respectively.

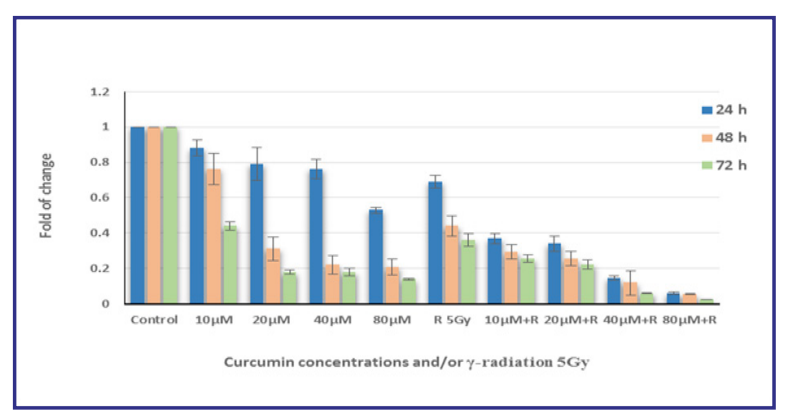

Fig. (6): MMP9 gene expression in HepG2 cell line treated with curcumin and or 5 Gy $\gamma$-irradiation \pm S.D, $\mathrm{P} \leq 0.05$.

Figure (7) shows a decrease in TAC in cells treated with curcumin with all concentrations when compared to control. At 20, 40 and $80 \mu \mathrm{M}$ concentrations of curcumin at $24 \mathrm{~h}$ the mean values were $0.13,0.17$, and $0.18 \mathrm{mM} / \mathrm{L}$ respectively. At $48 \mathrm{~h}$ they were $0.34,0.37$, and $0.45 \mathrm{mM} / \mathrm{L}$ with 20,40 and 80 $\mu \mathrm{M}$ respectively. Finally, at $72 \mathrm{~h}$ the mean values of TAC were $0.46,0.41$ and 0.35 with concentrations 20,40 and $80 \mu \mathrm{M}$ respectively.

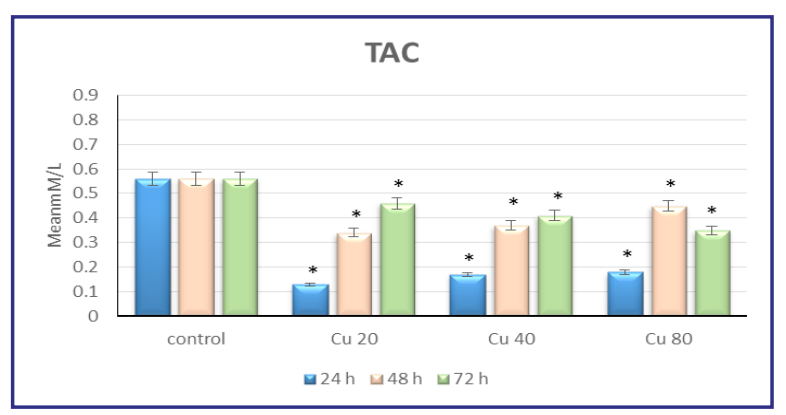

Fig. (7): Total antioxidant capacity $( \pm \mathrm{SD})$ in case of curcumin treatment, $\mathrm{P} \leq 0.05$.

Figure (8) shows a significant decrease of the TAC in all groups when compared with control. The mean values in 5Gy groups were $0.44,0.4$ and $0.5 \mathrm{mM} / \mathrm{L}$ at 24,48 and $72 \mathrm{~h}$ respectively. Between some groups there were no significant differences, as in $5 \mathrm{~Gy}$ and $40 \mu \mathrm{M}$ at $24 \mathrm{~h}$, also at $72 \mathrm{~h}$ there were no significant difference between 40 and $80 \mu \mathrm{M}$. When $5 \mathrm{~Gy}$ was combined with curcumin the values were $0.46,0.44,0.43,0.31,0.32,0.37,0.47,0.48$ and 0.48 at 24,48 and $72 \mathrm{~h}$ and curcumin concentrations 20 , 40 and $80 \mu \mathrm{M}$ respectively.

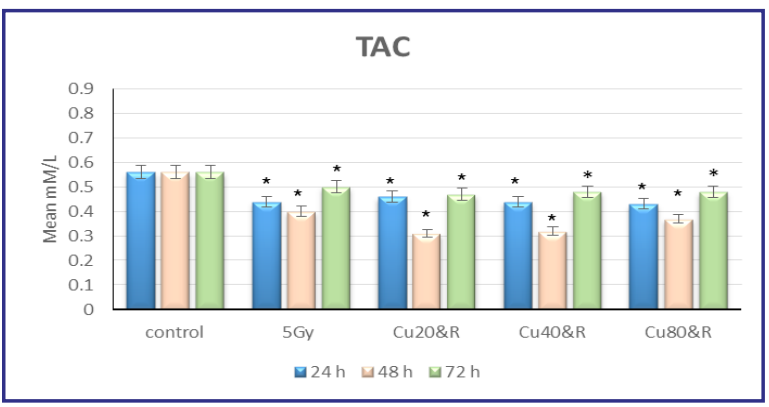

Fig. (8): Total antioxidant capacity $( \pm \mathrm{SD})$ in case of curcumin treatment combined with $5 \mathrm{~Gy} \gamma$-irradiation, $\mathrm{p} \leq 0.05$.

\section{DISCUSSION}

The inhibitory effects were increased in high doses of curcumin treatment and by time especially above $40 \mu \mathrm{M}$ and after $72 \mathrm{~h}$ of incubation. These results are in agreement with the results of Bharti $\boldsymbol{e t}$ al. (2003) and Li et al. (2015). The previous studies referred that the proliferation and survival of almost types of tumor cells has been inhibited by curcumin. They suggest that the action of curcumin-induced cell death is by the inhibition of growth and proliferation of cancer cells, and the activation of cell death pathways.

2Gy $\gamma$-radiation induces cell toxicity on HepG2 cell lines, but the effect was lower than for 5Gy, which may be attributed to the mechanism of cell recovery due to the low dose. Furthermore, the results revealed that 5Gy $\gamma$-radiation dose cytotoxicity is time dependent. These results are in agreement with Chung et al. (2015) and Girdhani et al. (2009), who reported that $\gamma$-radiation can induce cell death in a dose-and time-dependent manner. Moreover, Chung et al. (2015) stated that radiation-induced apoptosis 
is due to the generation of reactive oxygen species (ROS) in tumor cells, which causes oxidative damage to the cells.

\section{The effect of curcumin combined with $\gamma$-radiations:}

The cell viability was decreased significantly when treated with curcumin then exposed to $\gamma$ radiations than in case of radiation only. This effect was in a dose-and time-dependent manner. These results are in agreement with Girdhani et al. (2009), who found that the combination treatment of cancer cells with curcumin followed by radiation significantly enhanced the cell death, and this effect was increased with dose and time of incubation.

\section{The effect of curcumin and/or radiation on gene expression:}

The tumor suppressor gene p53 becomes activated in response to stress, such as DNA damage, oxidative stress, but in normal condition p53 was at low level. This study demonstrated that HepG2 cells when feeding with curcumin the viability was decreased in a dose- and time-dependent manner, which was agreed with Bharti et al. (2003) and $\mathbf{~ L i}$ et al. (2015). In case of curcumin alone with 10, 20, 40 , and $80 \mu \mathrm{M}$ concentrations, p53 gene expression increase with increase of curcumin concentration and time of treatment. P53 expression at $72 \mathrm{~h}$ was 5.2 \pm 0.38 fold relative to control with $80 \mu \mathrm{M}$ curcumin treatment. This result is in agreement with Li et al., 2015 and Gallardo \& Calaf, 2016. Who reported that curcumin down regulate MDM2 which is considered the negative inhibitor of p53 expression, and this lead to increase in p53 gene expression. The p53 expression when exposed to $5 \mathrm{~Gy} \gamma$-radiation was increased in a dose and time dependent manner which is in agreement with Veeraraghavan et al. (2010). This effect was increased when 5Gy was combined with curcumin by time and concentrations (Veeraraghavan et al., 2010).

Her2/neu gene expressions decreased on HepG2 cells when treated with curcumin and this effect in- creased by the increase in dose and time. These results agree with Lai et al. (2012), who reported that cancer cells treated with curcumin, the phosphorylation of Akt and MAPK was decreased, combined with the down regulation of HER-2 oncoprotein, in a dose-dependent manner (Lai et al., 2012). The MMP9 decreased in a dose and time dependent manner when treated with curcumin leading to inhibitory effects on HepG2 cell adhesion and invasion. These results agree with Tong $\boldsymbol{e t}$ al. (2016) who indicated that curcumin probably can inhibit MMP9 transcription by suppressing NF-kB DNA binding activity to MMP9 promoter region. So, the anti-metastatic effects of curcumin in cancer cells may be mediated by inhibition of the NF- $\mathrm{KB}$ signaling pathway (Killeen et al., 2009 and Tong et al., 2016).

\section{Total antioxidant capacity (TAC):}

Reactive oxygen species (ROS) play an important role in many clinical diseases including cancer (Koren et al., 2008). The antioxidants play a crucial role in the defence against oxidative stress. TAC includes enzymatic and non-enzymatic constituents. Our results revealed that when HepG2 cells were treated with curcumin, this cause a decrease in TAC, which is in line with the results of Satson et al. (2017) who reported that there is a reduction of SOD activity (The main antioxidant enzyme) in D. discoideum strain after treatment by curcumin for 24 hours and this was accompanied by a decrease in the expression of sodA, sodB and sod 2 mRNA and suggested that curcumin is not acting as an antioxidant in D. discoideum cells. In the same direction, previous studies suggest that curcumin can act as a pro-oxidant in some situations (Khan et al., 2012 and Aggeli et al., 2013). Swatson et al., 2017 try a variety of existing mutant strains with deleted or over-expressed genes in knowing regulatory/signaling pathways or genes involved in generating or scavenging ROS were tested for their response to curcumin. They explain the negative effect of curcumin on antioxidant enzymes through the relation 
between curcumin and Protein Kinase A (PKA). The cAMP-depend protein Kinase A is known to regulate the activity of a wide number of proteins.

Moreover it has important regulatory functions in human, zebrafish, drosophila, yeast, and D. discoideum. Swatson et al., 2017 reported that cells with an inactive form of PKA (pkaCnull or pkaROE) showed increased resistance to curcumin than the parent strain and curcumin had little to no effect on catalase A and SOD activity in pkaC null cells suggesting that ROS may not be up-regulated as observed with the wild-type strain.

Radiation exposure induced generation of reactive oxygen species (ROS) on HepG2 cells, which consequently reduces the TAC in a time-dependent manner at $24 \mathrm{~h}$, and $48 \mathrm{~h}$, but at $72 \mathrm{~h}$ there was unexpected elevation which may be due to cell repair mechanism. This result agrees with (Nada 2013). When radiation was combined with curcumin the TAC was higher than in the case of radiation alone, but still lower than its respective value in the untreated group.

\section{Conclusion}

Curcumin can effect on viability, apoptosis, and invasion of cancer cell. Curcumin can sensitize HepG2 cells to radiation. Curcumin combined with radiation probably have therapeutic effect on cancer.

\section{REFERENCES}

- Aggarwal, B.B.; Kumar, A. and Bharti, A.C. (2003): Anticancer potential of curcumin: preclinical and clinical studies. Anticancer Res. J., (23): 363.

- Aggeli, I.K.; Koustas, E.; Gaitanaki, C. and Beis, I. (2013): Curcumin acts as a pro-oxidant inducing apoptosis via JNKs in the isolated perfused Rana ridibunda heart. Exp. Zool. A Ecol. Genet. Physiol. J., 319(6): 328 .
- Apoorv, TS.; Babu, PP.; Meese S.; Gai PP.; Bedu-Addo, G. and Mockenhaupt, F.P. (2015): Matrix metalloproteinase-9 polymorphism $1562 \mathrm{C}>\mathrm{T}$ (rs3918242) associated with protection against placental malaria. The Am. J., Trop. Med. Hyg. 93 (1): 186.

- Badra, G.; Lotfy, M.; El-Refaie, A.; Obada, M.; Abdelmonem, E.; Kandeel, S. and Fathy, A. (2010): Significance of serum matrix metalloproteinase- 9 and tissue inhibitor of metalloproteinase-1 in chronic hepatitis C patients. Acta Microbiol__Immunol. Hung. J., 57(1): 29.

- Bharti, A.C.; Donato, N.; Singh, S.; and Aggarwal, B.B. (2003): Curcumin (diferuloylmethane) down-regulates the constitutive activation of nuclear factor-kappa B and IkappaBalpha kinase in human multiple myeloma cells, leading to suppression of proliferation and induction of apoptosis. Blood J., 101: 1053 .

- Chan, WH.; Wu, C.C.; and Yu, J.S. (2003): Curcumin inhibits UV irradiation-induced oxidative stress and apoptotic biochemical changes in human epidermoid carcinoma A431 cells. J., Cell Biochem., 90: 327.

- Chung, D.M.; Kim, J.H. and Kim, J.K. (2015): Evaluation of MTT and Trypan Blue assays for radiation-induced cell viability test in HepG2 cells Int. J. Radiat. Res., 13(4): 331.

- Cuadros, M.; Talavera, P.; Lopez, F.J.; GarcíaPerez, I.; Blanco, A. and Concha, A. (2010): RealTime RT-PCR Analysis for Evaluating the Her2/neu Status in Breast Cancer. J., Pathobiology, 77:38.

- El-Naggar A.M. (2009): Medical Radiation Biology. Google Books. Medical_Radiation_Biology.html.

- $\quad$ El-Serag, HB. and Rudolph, KL. (2007): Hepatocellular carcinoma: epidemiology and molecular carcinogenesis. J. Gastroenterology, 132: 2557. 
- Estella, C.; Herrer, I.; Atkinson, S.P.; Quinonero, A.; Martınez, S.; Pellicer A. and Simon, C. (2012): Inhibition of Histone Deacetylase Activity in Human Endometrial Stromal Cells Promotes Extracellular Matrix Remodeling and Limits Embryo Invasion. PLOS ONE J., 7(1): e30508.

- Fung, S.K. and Lok, A.S. (2005): Management of patients with hepatitis B virus-induced cirrhosis. Hepatol. J., 42: 54.

- Gallardo, M. and Calaf, G.M. (2016): Curcumin and epithelial-mesenchymal transition in breast cancer cells transformed by low doses of radiation and estrogen. Int. J. Oncol., 48(6): 2534.

- Girdhani, S.; Ahmed, M.M. and Mishra, K.P. (2009): Enhancement of Gamma Radiation-induced Cytotoxicity of Breast Cancer Cells by Curcumin. Mol. Cell. pharmacol. J., 1(4): 208.

- Khan, M.A.; Gahlot, S. and Majumdar, S. (2012): Oxidative Stress Induced by Curcumin Promotes the Death of Cutaneous T-cell Lymphoma (HuT-78) by disrupting the Function of Several Molecular Targets. Mol. Cancer Ther. J., 11:1873.

- Killeen, S.D.; Wang, J.H.; Andrews, E.J. and Redmond, H.P. (2009): Bacterial endotoxin enhances colorectal cancer cell adhesion and invasion through TLR-4 and NF-kappaB-dependent activation of the urokinase plasminogen activator system. Br. J., Cancer 100: 1589.

- Koracevic, D.; Koracevic, G.; Djordjevic, V.; Andrejevic, S. and Cosic, V. (2001): Method for the measurement of antioxidant activity in human fluids. Clin. Pathol. J., 54 (5): 356.

- Koren, E.; Zverev, I.; Ginsburg, I. and Kohen, R. (2008): Supplementation with antioxidants fails to increase the total antioxidant capacity of several cell lines in culture. Biomed. Pharmacother., 62, (3):179.
- Lai, H.; Chien, S.; Kuo, S.; Tseng, l.; Lin, H., Chi, C. and Chen, D. (2012): The Potential Utility of Curcumin in the Treatment of HER-2-Overexpressed Breast Cancer: An In Vitro and In Vivo Comparison Study with Herceptin. Evid. Based Complement. Alternat. Med., 12 pages Article ID 486568. doi. org/10.1155/2012/486568

- Li, W.; Wang, Y.; Song, Y.; Xu, L.; Zaho, J. and Fang, B. (2015): A preliminary study of the effect of curcumin on the expression of $\mathrm{p} 53$ protein in a human multiple myeloma cell line. Oncol. Lett., 9: 1719.

- Mitri, Z.; Constantine, T. and O'Regan, R. (2012): The HER2 Receptor in Breast Cancer: Pathophysiology, Clinical Use, and New Advances in Therapy. Chemoth. Res. Pract. J., 743193.

- Mosmann, T. (1983): Rapid colorimetric assay for cellular growth and survival: application to proliferation and cytotoxicity assays. Immunol. Methods J., 16; 65(1-2):55.

- Nada, A.S. (2013): Modulating efficacy of thyme oil in rats exposed to $\gamma$-radiation. Rad. Res. J., 6(1):35.

- Rivenbark, A. and Coleman, W. (2007): The use of epigenetic biomarkers for preclinical detection of hepatocellular carcinoma: potential for noninvasive screening of high-risk populations. Clin. Cancer Res. J., 13: 2309.

- Swatson, W.S.; Katoh-Kurasawa, M.; Shaulsky, G. and Alexander, S. (2017): Curcumin affects gene expression and reactive oxygen species via a PKA dependent mechanism in Dictyostelium discoideum. PLOS ONE J., 12(11): 10.1371.

- Tan, M. and Yu, D. (2007): Molecular mechanisms of erbB2-mediated breast cancer chemoresistance. Adv. Exp. Med. Biol. J., 608: 119.

- Tong, W.; Wang, Q.; Sun, D. and Suo, J. (2016): Curcumin suppresses colon cancer cell invasion via 
AMPK-induced inhibition of NF- $\kappa \mathrm{B}$, uPA activator and MMP9. Oncol. Lett., 12(5): 4139.

- Vandooren, J.; Van den Steen, P.E. and Opdenakker, G. (2013): Biochemistry and molecular biology of gelatinase B or matrix metalloproteinase-9 (MMP9) the next decade. Crit. Rev. Biochem. Mol. Biol. J., 48(3): 222.

- Veeraraghavan, J.; Natarajan, M.; Herman, T.S. and Aravindan, N. (2010): Curcumin-altered p53Response Genes Regulate Radiosensitivity in p53mutant Ewing's sarcoma cells, Anticancer Res. J., 30
(10): 4007 .

- Wade, M.; Wong, E.T.; Tang, M.; Stommel, J.M. and Wahl, G. (2006): Hdmx modulates the outcome of p53 activation in human tumor cells. Biol. Chem. J., 281 (44): 33036.

- Ziada, D.; El Sadany, S.; Soliman, H.; Abd-Elsalam, S.; Salama, M.; Hawash, N.; Selim, A.; Hamisa, M. and Elsabagh, H. (2016): Prevalence of hepatocellular carcinoma in chronic hepatitis $\mathrm{C}$ patients in Mid Delta, Egypt: A single center study. Egypt Nati. Canc. Inst. J., 28(4): 257. 


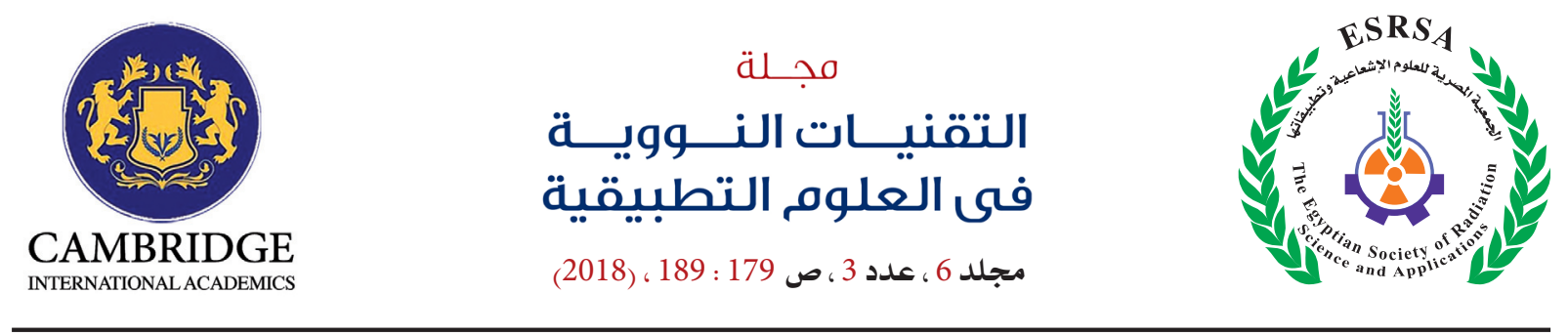

التأثير الجزيئى للكركم مدعوم بالإشعاع على خطوط خلايا سرطان الكبد

عزه السيد محمد السيد قايد' ـ طارق خالد عبد اللّه المغربى' ـ نجوى حسن على حسان'

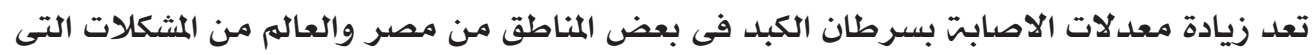

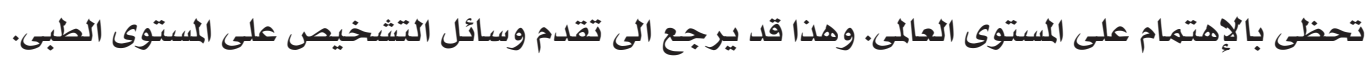

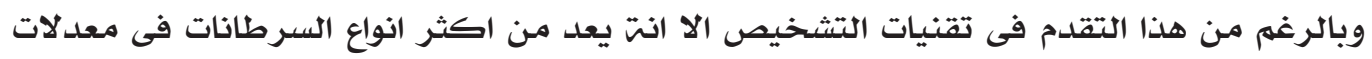

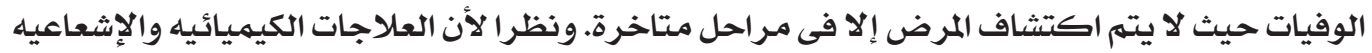

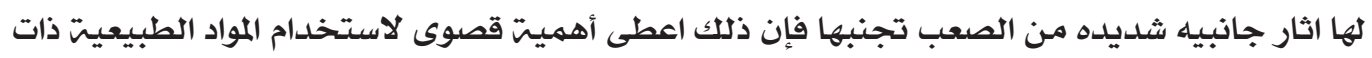

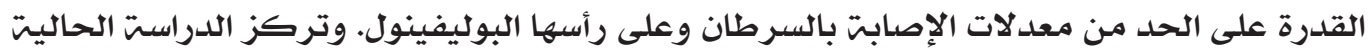

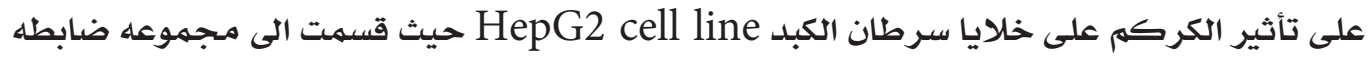

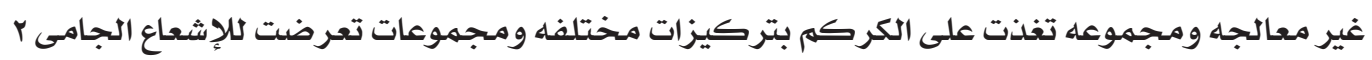

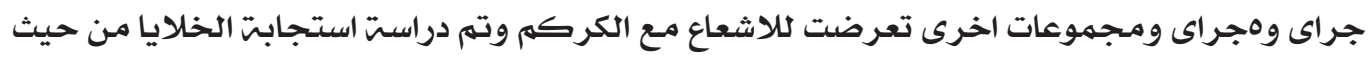

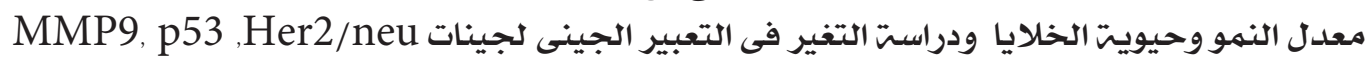

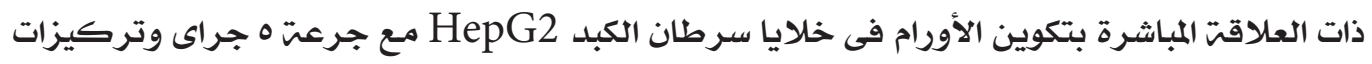

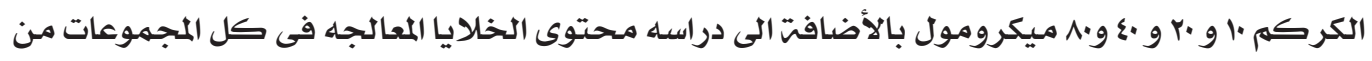

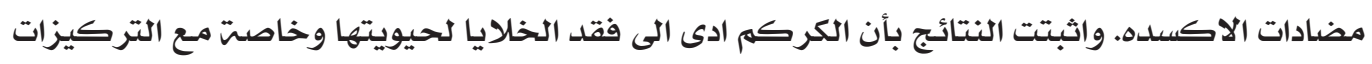

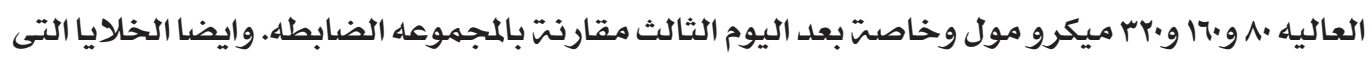

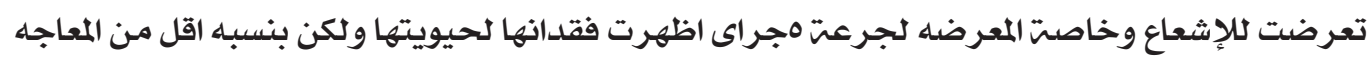

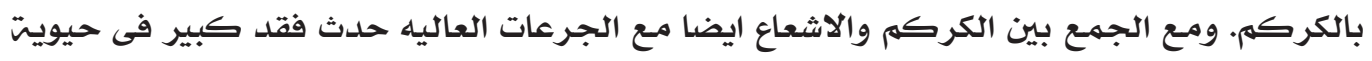

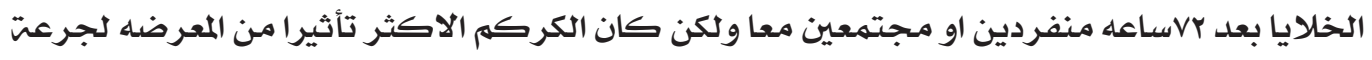

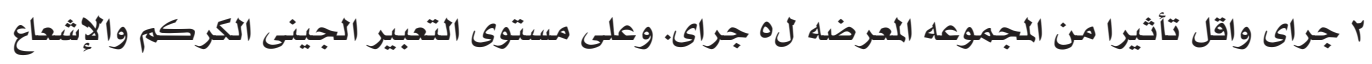

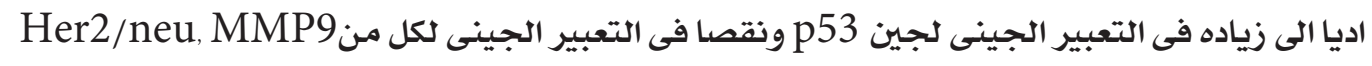

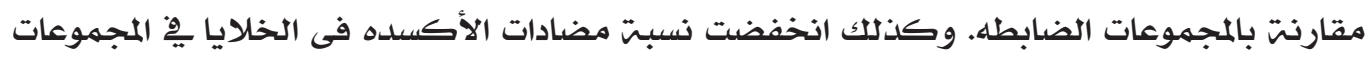

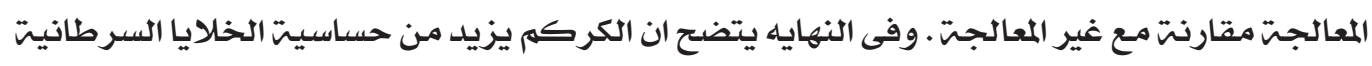
لكإِشعاع وبذلك يزيد من فاعليت العلاج بالإشعاع. 
